\title{
TEKNOLOGI SISTEM INFORMASI GEOGRAFIK (SIG) UNTUK MEMBANTU SINKRONISASI KEGIATAN PENATAAN LAHAN
}

\author{
Oleb \\ Sukendra Martha *)
}

\section{ABSTRACT}

The technology on Geographic Information System (GIS) which has been rapidly developed so far is very important role in supporting the land use management because it based in spatial/geopraphically referenced data. Geographic data and information which can be an input for GIS, must be based on topographic base maps or other thematic maps. GIS input can also be generated by the results of image processing. This article describes GIS technology for syncbronizing land use activities.

\section{INTISARI}

Teknologi Sistem Informasi Geografik yang berkembang pesat sekarang ini sangat penting perannya dalam menunjang sinkroniasi penataan wilayah karena didasari atas data dasar spatial yang bereferensikan lokasi geografis. Data atau informasi geografik yang dijadikan masukan bagi SIG dapat berasal dari petapeta dasar baku rupabumi atau tematik lainnya. Masukan SIG juga dapat berasal dari basil pemrosesan citra penginderaan jaub. Makalab ini menguraikan teknologi SIG untuk kepentingan sinkronisasi penataan laban.

\section{PENDAHULUAN}

Penataan lahan atau ruang bumi yang tidak didasari oleh pertimbangan informasi spasial yang lengkap dan da. pat dipercaya akan mempunyai dampak tidak terpadunya kegiatan pembangunan. Oleh karena itu suatu sistem informasi spasial yang mampu memproses dan menganalisis informasi tersebut untuk membantu pengambilan keputusan penatagunaan lahan adalah mutlak diperlukan. Sistem ini juga menjanjikan kontribusinya dalam rangka sinkronisasi kegiatan penataan la. han.

Berkembangnya penduduk dan kebutuhan terhadap bentuk-bentuk penatagunaan lahan yang bertujuan ganda (multi-purpose), prosedur perencanaan yang kompleks menjadi lebih penting tidak hanya untuk daerah industri tetapi juga wilayah yang sedang berkembang di pedesaan (Kenneweg, 1992). Sejalan dengan pernyataan tadi, BAKOSURTANAL dalam melaksanakan 
program-program survey dan pemetaannya, terutama pemetaan dasar rupabumi sclama ini juga tidak tcrlepas dari pertimbangan tersebut. Untuk dacrah yang telah padat penduduknya dengan aktivitas ekonomi yang lebih tinggi, scperti di Jawa, Bali dan Lombok dipetakan dengan skala 1:25.000 (membuat informasi yang relatif lebih detil), sedangkan untuk daerah yang lain, pemetaan masih dilakukan untuk skala yang lebih kecil, 1:50.000 (Suharto, 1993).

Selain peta rupabumi, data penginderaan jauh juga digunakan sebagai sumber input data/informasi spasial yang up to date. Sebagai data masukan tentunya peran data penginderaan jauh, peta-peta rupabumi maupun peta-peta tematik benar-benar sangat dipcrlukan. Data penginderaan jauh telah digunakan di banyak instansi, baik sebagai sumber potensi unsur-unsur data baru untuk SIG, yang kemudian dapat digabungkan dengan data SIG yang sudah ada, maupun sebagai bentuk alternatif dari perolehan data untuk satu unsur/lebih dari data yang terdefinisi dengan baik (Martha, 1993).

Informasi yang diperoleh dari citra inderaja dapat dikatakan sebagai data dasar geografi yang baku. Alasannya adalah bahwa pencerminan informasi bentang geografik yang apa adanya termaktub dalam gambaran citra penginderaan jauh baik foto udara maupun citra satelit. Meskipun data penginderaan jauh dapat juga diperoleh dengan berbagai variabel sensor, sudut peng. ambilan data, tinggi pemotretan dan lain-lain tetapi dibandingkan dengan variabilitas data geografik yang berasal dari sumber peta, data penginderaan jauh lebih mudah dijadikan rujukan untuk kepentingan SIG. Informasi dari peta-peta topografik/tematik yang ditransformasikan ke dalam data set digital untuk tujuan SIG ini meliputi topografi, jenis liputan lahan, potensi vegetasi alam, tipe tanah dll. (Kenneweg, 1992).

Kesemua informasi tadi scbenarnya tidak terlepas dari aspek perbendaharaan data dasar. Karena perbendaharaan data dasar geografi yang baku sangat diperlukan untuk membangun suatu Sistem Informasi Geografik. Data dasar geografik/topografik yang lengkap akan berperan dalam teknologi SIG ini yang nantinya dapat dimanfaatkan sebagai alat bantu dalam menentukan kebijakan pembangunan, baik di tingkat nasional maupun tingkat daerah.

Masalah pembinaàn perbendaharaan data-data dasar dan perpetaan wilayah nasional, memang sudah menjadi salah satu tugas pokok BAKOSURTANAL (Keppres 83/69). Tidak hanya itu bahkan data-data dasar tadi harus diusahakan/diupayakan oleh BAKOSURTANAL agar kesiapan dalam mengoperasionalisasikan Sistem Informasi Geografik Nasional (SIGNAS) dapat terwujud. Kemampuan ini akan dapat dimanfaatkan untuk berbagai tujuan termasuk untuk penataan lahan ini.

\section{BERBAGAI KONSEP MENGENAI SIG}

Sebelum membahas lebih jauh, ada baiknya diperkenalkan apa pengertian sistem informasi geografik, dan bagaimana teknologi ini dapat menganalisis dan memproses data geografik yang ada.

SIG sebenarnya bertujuan untuk menkombinasikan informasi geografik dalam berbagai layers dengan berbagai data atribut dalam rangka menganalisa, 
menjelaskan, mengevaluasi, mendesain atau merancang kcbutuhan tata guna lahan tertentu atau perubahan penggunaan lahan.

Konsep SIG scharusnya tidak harus dengan komputer, karena idea awal konsep SIG ini sebenarnya dapat dilakukan dengan menumpangtindihkan peta-peta tematik pada format dan skala yang sama. Kenneweg (1992) tidak sependapat dengan pernyataan bahwa SIG adalah sistem yang sepenuhnya teknis, karena idea tersebut dalam berbagai kasus dapat dilaksanakan tanpa komputer. Walaupun demikian perkembangan teknologi komputer sendiri yang dapat membantu secara lebih cepat dan efisien dalam memproses data-datanya. Konsep SIG berkomputer menawarkan proses pemanipulasian data atau penganalisisan data secara cepat untuk keperluan penataan lahan.

\section{PERLUNYA SINKRONISASI DALAM PENATAAN RUANG}

Beberapa kasus ketidakterpaduan dalam penataan lahan memberikan dampak yang kurang positif, baik dari aspek lingkungan, fisik maupun sosial budaya. Dari aspek lingkungan, tidak sinkronnya penataan lahan dapat berakibat buruk terhadap lingkungan secara umum. Dari aspek fisik lahan, sebagai akibat penataan lahan yang kurang pas, boleh jadi lahan-lahan produktif tidak dimanfaatkan untuk keperluan peningkatan produksi pertanian, tetapi pemanfaatan lain yang bclum tentu keperluan peningkatan produksi pertanian, tetapi pemanfaatan laun yang belum tentu akan dapat memakmurkan masyarakat. Dari segi sosial budaya, penataan lahan yang kurang tepat akan memberikan dampak kerawanan sosial, konflik antar kepentingan, kepincangan ekonomi dll.

Untuk membantu dalam upaya sinkronisasi penataan lahan ini pcrlu ditunjang dengan data-data spasial dan statistik yang komprehensif. Untuk maksud tsb. juga mutlak diperlukan adanya data dasar yang baik.

\section{PETA DASAR UNTUK SIG}

Sebagai masukan bagi SIG peta-peta yang baku juga dibutuhkan dalam rangka perolehan hasil yang baik dalam analisis penataan lahan. Peta rupa. bumi sebagai peta dasar dapat membantu analisis tsb. Analisis yang memerlukan integrasi berbagai informasi tematik akan merujuk pada peta dasár tadi. Peta liputan lahan (land cover) sebenarnya sangat dibutuhkan sebagai dasar dalam rangka inventarisasi sumberdaya alam dan studi kemampuan lahan (Kalenskt, 1992). Informasí tersebut bersama-sama dengan peta rupabumi tadi merupakan kunci utama sebagai input SIG.

Peta dasar rupabumi yang digunakan untuk penataan lahan harus disesuaikan dengan skalanya. Karena skala menginformasikan tingakt ketelitian informasi syang dikandungnya. Sebagai contoh, peta dengan skala 1:250.000 dapat dimanfaatkan untuk membantu perencanaan wilayah di tingkat propinsi, sedangkan peta 1: 50.000 dapat digunakan untuk perancangan wilayah Kabupaten Dati-II. Ketidakseragaman level informasi yang dikandung dari suatu peta akan berakibat ketidakseragaman/kebcradaan hasil analiss dari pengintegrasian peta yang dimanipuiasikan SIG. Demikian juga tingkat informasi pada citra foto udara maupun citra satelit. Analisa yang salah atau 
kurang tepat akan mempengaruhi proses pembuatan keputusan pengelolaan sumberdaya yang tidak benar (Martha, 1988).

Untuk perencanaan tata ruang atau tata guna lahan parameter tambahan yang sangat penting adalah ketinggian, kemiringan lereng, aspek, jarak ke jaringan jalan dan variabel-variabel yang merefleksikan ekonomi dari berbagai kemungkinan pilihan-pilihan penatagunaan lahan. Semua parameter lahan yang menjadi input SIG harus terlebih dahulu mempunyai standarisasi tertentu. Sebagai misal, pembakuan klasifikasi liputan lahan di Indonesia yang mendasarkan pada analisa citra satelit telah juga dilakukan. Sistem klasifikasi tata guna lahan yang diusulkan Malingreau pada tahun 1981, dan dilanjutkan oleh BAKOSURTANAL pada tahun 1985. Walaupun klasifikasi yang diusulkan masih pada tiga klasifikasi baku terbatas liputan lahan: (a) Skala 1: 1000.000 yang didasarkan pada citra Landsat skala 1: 250.000 ; (b) skala 1: 250.000 yang didasarkan pada dan digeneralisasikan dari citra Landsat berskala 1: 250.000 dan foto udara \pm 1 : 100.000, dan (c) skala 1: 50.000 yang didasarkan pada foto udara 1: 50.000

\section{KESIMPULAN}

Seperti discbutkan, data geografik yang diperlukan untuk SIG dapat berasal dari berbagai sumber: peta manual, peta digital, citra penginderaan jauh atau sumber lainnya sebagai input. Semakin lengkapnya 'spatial data base' yang dibangun, berasal dari berbagai sumber tadi, akan semakin kuatnya SIG untuk dimanfaatkan untuk tujuan penataan lahan. Penataan lahan yang baik dan bijaksana tentu memerlukan berbagai pertimbangan-pertimbangan kondisi fisik, sosial ekonomi maupun budaya yang ada pada lokai lahan tersebut. Apabila pertimbangan ini betul-betul diperhatikan dan ditepati maka upaya-upaya dalam penataan lahan akan berjalan dengan baik dan sinkron tanpa harus saling berbenturan antar kepentingan. Dan teknologi SIG mampu melaksanakản kajian/ analisis pertimbangan berbagai kondisi geografik tadi untuk membantu mensinkronkan pentaan lahan. 


\section{DAFTAR PUSTAKA}

Kalensky, D.7. 1992. "Iand Cover Mapping by Satellites: Challenge and Ilope for Developing Countries", dalam Application of Remote Sensing and Geographic Information Systems in Environmental and Monitoring, Bayer, I. and Runkel, M. (ed.), DSE, ZEL, FAO, 1992, pp. 9-22.

Kenneweg, H. 1992. "The Use of GIS in Lanscape Planning", dalam Application of Remote Sensing and Geograpbic Information Systems in Environmental and Natural Resources Management and Monitoring, Bayer, I. and Runkel, M. (ed.), DSE, ZEL, FAO, 1992, 265-280.

Marble. D.F. dan Peuquet D.J. 1983. "Geographic Information System and Remote Sensing", dalam Manual of Remole Sensing (Colwell, R.N. editor), ASP, Virginia.

Martha, S. 1988. Mapping/Survey Methods and GIS as Palnning Tools, Training Course on Principle of Coastal Resouces Management, NSC ASEAN/US CRM Project, Jakarta, April 3-16, 1988.

Martha, S. 1993. Peran Data Dasar Geografi Buku untuk Operasionalsasi GIS, Pertemuan Ilmiah Tabunan ke III MAPIN, Yogyakarta, 1-2 Desember 1993.

Martha, S. 1994. Sinergi Penginderaan Jauh dengan SIG uniuk Keperluan Analisis Wilayah, Seminar Sehari Jurusan Geografi UI dengan Forum Komunikasi Geografi UI, Jakarta, 9 Februari 1994.

Suharto, P. 1993. Perkembangan Pemetaan Dasar Nasional, Majalab Semi Ilmiab Geo-Informatika, Vol I, No. 2, Nopember 1993. 